\title{
Rancang Bangun Electrocardiography, Galvanic Skin Response dan Skin Temperature untuk Mendeteksi Stres pada Manusia
}

\author{
Bangkit Nata Satria Muhardiani, Rachmad Setiawan dan Fauzan Arrofiqi \\ Departemen Teknik Biomedik, Institut Teknologi Sepuluh Nopember (ITS) \\ e-mail: rachmad@bme.its.ac.id
}

\begin{abstract}
Abstrak-Stres merupakan masalah umum yang terjadi dalam kehidupan umat manusia yang disebabkan oleh banyak hal seperti kekhawatiran keuangan, pekerjaan, bahkan lingkungan sosial. Menurut saintis Hans Selte - the father of stress research stres adalah pangkal dari banyak penyakit. Dalam dunia kesehatan, stres sangat berdampak besar dalam cikal-bakal penyakit yang jauh lebih berbahaya seperti meningkatkan kemungkinan terkena jantung koroner, meningkatkan tekanan darah, dan meningkatkan kemungkinan infark miokard. Dalam lingkungan akademik, stres merupakan pengalaman yang paling sering dialami oleh para siswa, baik yang sedang belajar di tingkat sekolah ataupun di perguruan tinggi. Hal tersebut dikarenakan banyaknya tuntutan akademik yang harus dihadapi, seperti ujian, tugas-tugas, dan lain sebagainya. Sejumlah peneliti telah menemukan bahwa siswa yang mengalami stres akan cenderung menunjukkan kemampuan akademik yang menurun, kesehatan yang memburuk, depresi, dan gangguan tidur. Maka dari itu dibuatlah alat instrumentasi Electrocardiography (ECG), Galvanic Skin Response (GSR), Skin Temperature (ST) dengan mengunakan metode Fuzzy Logic Controller (FLC) sebagai decision maker. Dari pengambilan data 10 subjek dilakukan pengujian menggunakan metode Stroop Test, hasilnya variabel ECG dan GSR memiliki korelasi yang tinggi sekitar $80 \%$ dan $90 \%$ yang berarti nilai ECG dan GSR mengalami kenaikan sesuai dengan kenaikan stres. Sedangkan untuk ST korelasinya hanya 40\%. Namun secara keseluruhan berdasarkan hasil fuzzy didapati bahwa $100 \%$ subjek mengalami peningkatan stres pada saat pengujian metode Stroop Test. Selain itu, hasil deteksi stres dari alat yang telah dibuat dibandingkan dengan hasil survey psikologis untuk memvalidasi hasil akhir, didapati akurasi $90 \%$ dengan satu hasil salah dan sembilan hasil deteksi benar. Ini menunjukan bahwa sistem yang diciptakan sudah berjalan dengan baik.
\end{abstract}

Kata Kunci-Stres, Electrocardiography, Galvanic Skin Response, Skin Temperature, Fuzzy Logic Controller.

\section{PENDAHULUAN}

$\mathrm{S}_{\mathrm{k}}^{\mathrm{T}}$ TRES merupakan masalah umum yang terjadi dalam kehidupan umat manusia dan dewasa kini stres merupakan sebuah atribut kehidupan modern. Hal ini dikarenakan stres sudah menjadi bagian hidup yang tidak bisa terelakkan baik di lingkungan sekolah, kerja, keluarga, atau dimanapun, stres bisa dialami oleh seseorang [1]. Stres adalah tekanan internal maupun eksternal serta kondisi bermasalah lainnya dalam kehidupan. Dalam definisi lain stres juga merupakan suatu keadaan tertekan baik itu secara fisik maupun psikologis.
Dalam dunia kesehatan, stres sangat berdampak besar dalam cikal-bakal penyakit yang berbahaya seperti meningkatkan kemungkinan terkena jantung koroner, meningkatkan tekanan darah, dan meningkatkan kemungkinan infark miokard. Bahkan dalam jangka waktu yang lebih lama, stres dapat menyerang tubuh manusia dalam hal penekanan sistem kekebalan tubuh, penghambatan respon inflamasi, infentilitas dan penyakit diabetes [2]. Menurut saintis Hans Selte - the father of stress research yang memperkenalkan terori bahwa stres adalah pangkal dari banyak penyakit [3] .

Dalam lingkungan akademik, stres merupakan pengalaman yang paling sering dialami oleh para siswa, baik yang sedang belajar di tingkat sekolah ataupun di perguruan tinggi. Hal tersebut dikarenakan banyaknya tuntutan akademik yang harus dihadapi, misalnya ujian, tugas-tugas, dan lain sebagainya. Sejumlah peneliti telah menemukan bahwa siswa yang mengalami stres akan cenderung menunjukkan kemampuan akademik yang menurun, kesehatan yang memburuk, depresi, dan gangguan tidur [1].

Secara umum alur terjadinya stres berawal dari rangsang yang berasal dari luar dan dalam tubuh yang akan diteruskan pada sistem limbik sebagai pusat pengatur adaptasi. Sistem limbik meliputi thalamus, hipothalamus, amigdala, hippocampus dan septum. Hipothalamus memiliki efek yang sangat kuat pada hampir seluruh sistem visceral tubuh kita dikarenakan hampir semua bagian dari otak mempunyai hubungan dengannya. Maka hipothalamus dapat merespon rangsang psikologis dan emosional. Peran hypothalamus terhadap stres meliputi empat fungsi spesifik. Fungsi tersebut adalah; (1) menginisiasi aktivitas sistem saraf otonom; (2) merangsang hipofise anterior memproduksi hormon ACTH;( 3) memproduksi ADH atau vasopressin; (4) merangsang kelenjar tiroid untuk memproduksi hormon tiroksin. Maka, situasi stres ini mengaktivasi hipotalamus yang selanjutnya mengendalikan dua sistem neuroendokrin, yaitu sistem simpatik dan sistem korteks adrenal. Sistem saraf simpatik berespons terhadap impuls saraf dari hipotalamus yaitu dengan mengaktivasi berbagai organ dan otot polos yang berada di bawah pengendaliannya, sebagai contohnya, ia meningkatkan kecepatan denyut jantung dan mendilatasi pupil perubahaan suhu tubuh , telapak kaki dan tangan terasa dingin hingga keluar keringat pada telapak tangan. Dengan keberadaan stres yang tidak bisa terelakan oleh setiap orang maka dari itu, dirasa perlu 


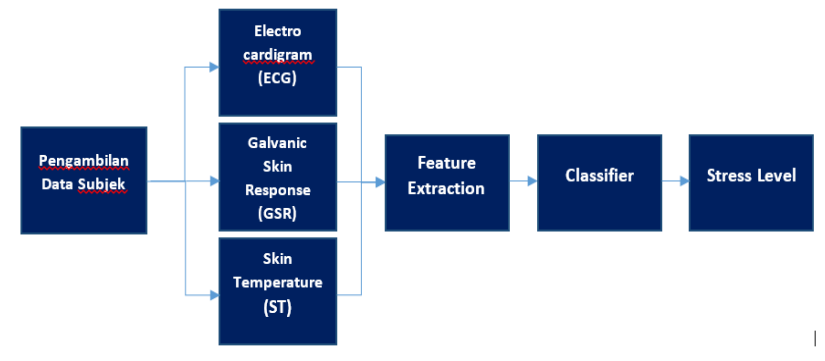

Gambar 1. Diagram blok system
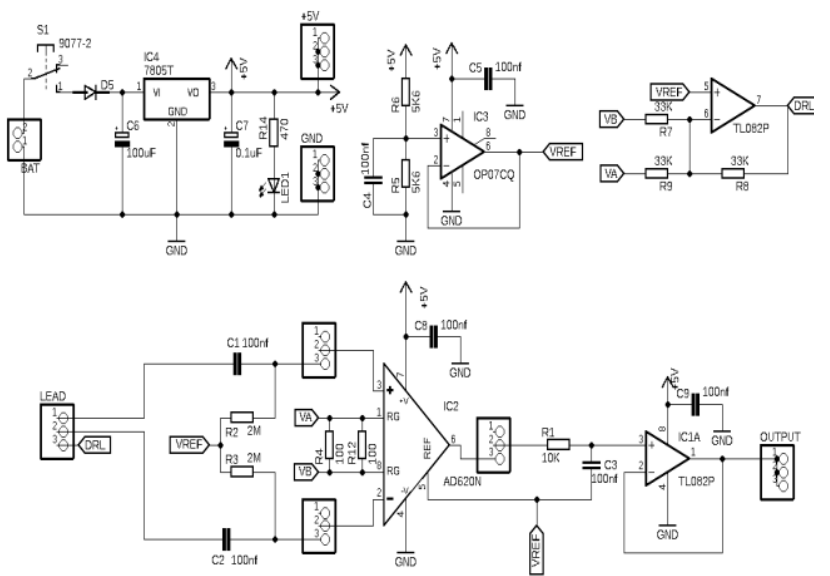

Gambar 2. Instrumentasi rancangan ECG

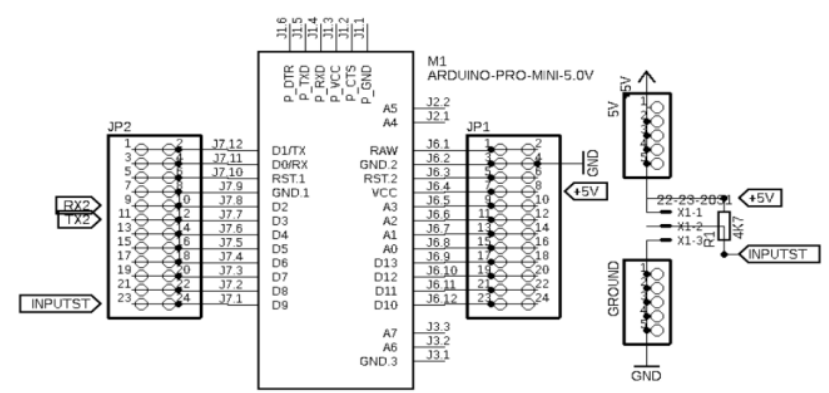

Gambar 3. Arduino pro mini dan sensor DS18B20 instrumentasi ST

untuk menciptakan suatu alat yang dapat mengidentifkasi tingkatan stres. Dewasa kini mengidentifikasi permasalahan stres melalui metode psikologi sudah banyak digunakan. Namun dirasa perlu untuk mengidentifikasi dan mengukur tingkat stres secara fisiologi menggunakan sinyal tubuh seperti Galvanic Skin Response (GSR), Electrocardiograph (ECG), dan Skin Temperature (ST). Instrumentasi tersebut merupakan beberapa prediktor yang dianggap mampu untuk mendeteksi tingkat stres seseorang dengan gabungan metode fuzzy yang akan menjadi decision maker untuk mengklasifikasikan tingkat stres menjadi beberapa tingkatan.

\section{PERANCANGAN SISTEM}

\section{A. Diagram Blok Sistem}

Diagram blok keseluruhan sistem ditunjukkan pada Gambar 1. Terdapat 3 jenis instrumentasi yang digunakna, yaitu electrocardiography (ECG) untuk mendapatkan sinyal jantungnya dan mengukur Heart Beat-nya (HB),skin temperature (ST) untuk mengukur suhu tubuh (suhu kulit) dan

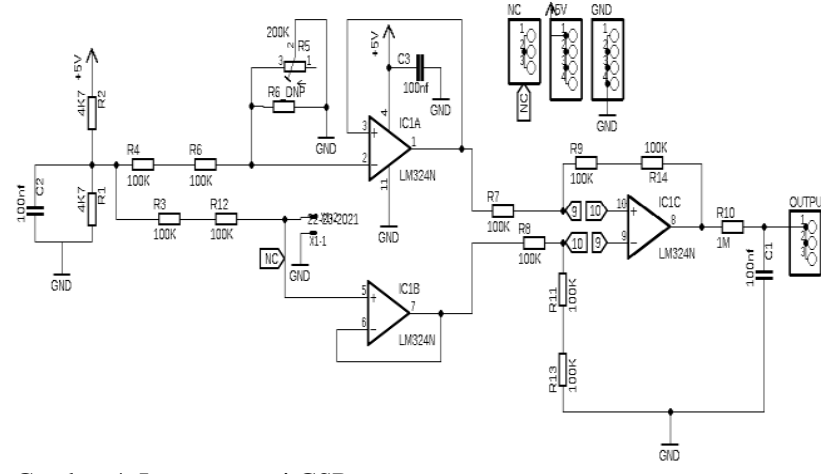

Gambar 4. Instrumentasi GSR

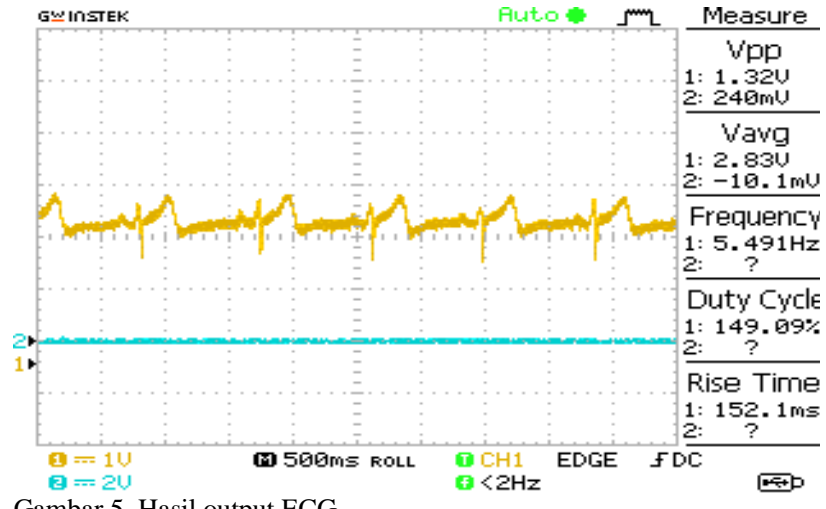

Gambar 5. Hasil output ECG

Galvanic Skin Response (GSR) untuk mengukur konduktivitas kulit manusia. Ketiga instrumentasi ini akan digunakan secara bersamaan untuk mengambil tubuh yang diinginkan. Khusus unutk instrumentasi ECG akan dilakukan proses feature extraction terlebih dahulu untuk mendapatkan nilai HB-nya. Feature extraction tersebut menggunakan Metode Pan Tomkins untuk menghasilkan nilail HB dengan beberapa tahap yaitu: filterisasi menggunakan filter BPF, derivative untuk melihat slope sinyal, squaring function untuk menjadikan nilai sinyal menjadi positif, moving window integration untuk mendapatkan bentuk sinyal yang lebih mudah dianalisis, thresholding $R$ - $R$ interval untuk melakukan seleksi $\mathrm{R}$ wave dan menghitung HB. Setelah semua nilai didapatkan, nilai akan menjadi input dari metode Fuzzy Logic Controller untuk mendapatkan decision subjek dan akan digolongkan menjadi tingkatan stres tertentu. Diagram blok sistem dapat dilihat pada Gambar 1.

\section{B. Electrocardiography $(E C G)$}

Electrocardiography (ECG) adalah sebuah alat pencatat aktivitas jantung yang banyak digunakan untuk diagnosis penyakit jantung [4].ECG mengungkapkan informasi diagnostik yang paling berguna tentang keadaan jantung karena dapat merepresentasikan dalam bentuk gelombang sinyal jantung. ECG digunakan dalam penelitian sebagai salah satu alat monitoring kondisi jantung dan variabel pendukung dianosis. Dari sinyal jantung didapatkan morfologi yang akan diterjemahkan sebagai informasi heart rate dan interval QRS dengan menggunakan metode Pan-Tomkins sebagai parameter hasil ekstraksi fitur ECG. Instrumentasi ECG terdiri dari 


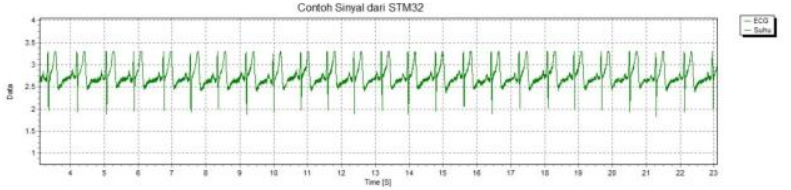

(a)

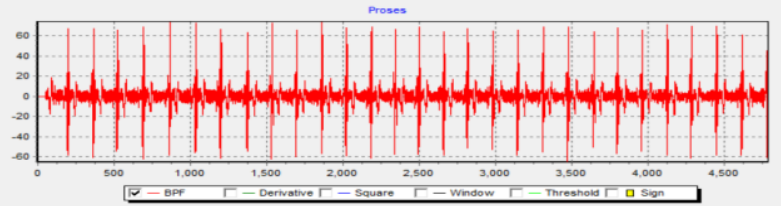

(b)

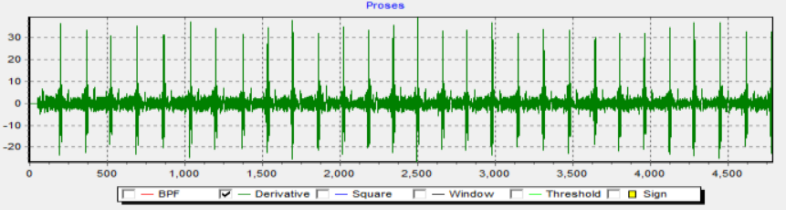

(c)

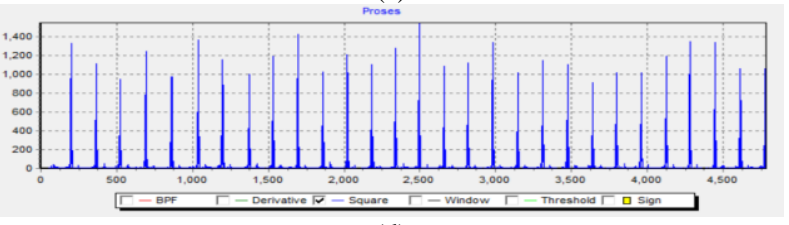

(d)

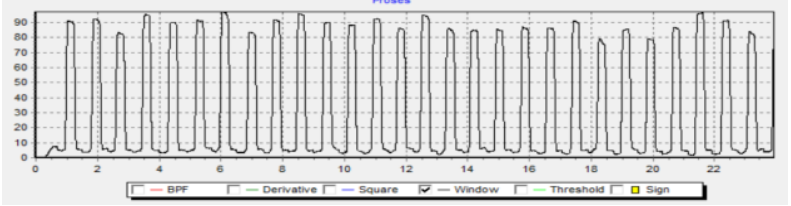

(e)

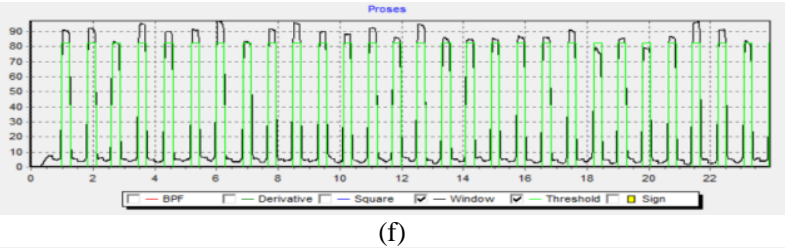

(f)

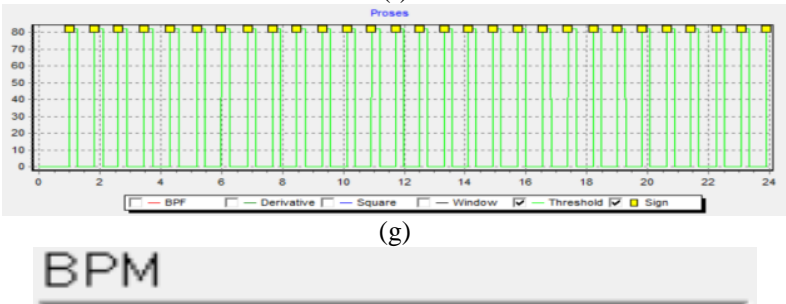

Heart Beat [19.895] $=69.32 \mathrm{BPM}$

(h)

Gambar 6. (a) Sinyal input ECG hasil ADC, (b) Filter BPF, (c) Derivative, (d) Squaring, (e) Window, (f) Threshold, (g) Sign, (h) Hasil BPM

rangkaian tegangan referensi, rangkaian High Pass Filter (HPF), rangkaian instrumentasi amplifier, rangkaian Low Pass Filter (LPF), rangkaian Driven Right Leg (DRL) dapat dilihat pada Gambar 2. Input dari instrumentasi ECG adalah raw signal yang didapatkan dari tubuh manusia melalui lead. Hasil output ECG dapat dilihat pada Gambar 5.
Tabel 1.

Rules heartbeat rendah

\begin{tabular}{lllll}
\hline \hline GSRIST & R & S & C & T \\
\hline R & S & S & R & R \\
S & S & S & S & R \\
C & $\mathrm{C}$ & S & S & S \\
T & $\mathrm{C}$ & $\mathrm{C}$ & $\mathrm{S}$ & $\mathrm{S}$ \\
\hline \hline
\end{tabular}

Tabel 2.

\begin{tabular}{lllll}
\multicolumn{5}{c}{ Rules heartbeat sedang } \\
\hline \hline GSRIST & R & S & C & T \\
\hline R & S & S & S & R \\
S & $\mathrm{C}$ & $\mathrm{S}$ & $\mathrm{S}$ & $\mathrm{S}$ \\
$\mathrm{C}$ & $\mathrm{C}$ & $\mathrm{C}$ & $\mathrm{S}$ & $\mathrm{S}$ \\
$\mathrm{T}$ & $\mathrm{C}$ & $\mathrm{C}$ & $\mathrm{C}$ & $\mathrm{S}$ \\
\hline \hline
\end{tabular}

Tabel 3 .

Rules heartbeat cukup

\begin{tabular}{lllll}
\hline \hline GSRIST & R & S & C & T \\
\hline R & C & S & S & S \\
S & $\mathrm{C}$ & $\mathrm{C}$ & $\mathrm{S}$ & $\mathrm{S}$ \\
$\mathrm{C}$ & $\mathrm{C}$ & $\mathrm{C}$ & $\mathrm{C}$ & $\mathrm{S}$ \\
$\mathrm{T}$ & $\mathrm{T}$ & $\mathrm{C}$ & $\mathrm{C}$ & $\mathrm{C}$ \\
\hline \hline
\end{tabular}

Tabel 4.

\begin{tabular}{llrrr}
\multicolumn{5}{c}{ Rules heartbeat tinggi } \\
\hline \hline GSRIST & R & S & C & T \\
R & C & C & S & S \\
S & $\mathrm{C}$ & $\mathrm{C}$ & $\mathrm{C}$ & $\mathrm{S}$ \\
$\mathrm{C}$ & $\mathrm{T}$ & $\mathrm{C}$ & $\mathrm{C}$ & $\mathrm{C}$ \\
$\mathrm{T}$ & $\mathrm{T}$ & $\mathrm{T}$ & $\mathrm{C}$ & $\mathrm{C}$ \\
\hline \hline
\end{tabular}

Ket. R : Rendah, S : Sedang, C : Cukup, T : Tinggi

\section{Skin Temperature (ST)}

Suhu tubuh atau temperatur tubuh adalah perbedaan antara jumlah panas yang diproduksi oleh proses tubuh dan jumlah panas yang hilang ke lingkungan luar. Temperatur tubuh manusia dapat diukur dengan menggunakan termometer. Pada perancangan hardware ini akan digunakan sensor temperatur DS18B20 yang ditempelkan di ketiak manusia. Pemilihan sensor temperature DS18B20 didasari oleh keunggulan yang dimilikinya, antara lain sebagai berikut: Unik 1-Wire interface hanya memerlukan satu pin port untuk komunikasi secara 1Wire, setiap perangkat memiliki kode serial 64-bit yang disimpan dalam sebuah ROM onboard, tidak memerlukan ada komponen tambahan, bekerja pada kisaran tegangan 3 sampai $5,5 \mathrm{~V}$, dapat mengukur suhu pada kisaran -55 sampai $125^{\circ} \mathrm{C}$, Akurasi $\pm 0,5^{\circ} \mathrm{C}$ akurasi dari suhu -10 sampai $85^{\circ} \mathrm{C}$, resolusi dapat dipilih oleh pengguna antara 9 sampai 12 bit $\left(0.5^{\circ} \mathrm{C}\right.$, $0.25^{\circ} \mathrm{C}, 0.125^{\circ} \mathrm{C}$, dan $0.0625^{\circ} \mathrm{C}$ ), kecepatan mengkonversi suhu maksimal $750 \mathrm{~ms}$ [5].

Selain itu pada penerapannya digunakan juga mikrokontroler tambahan untuk memudahkan pembacaan data sensor yaitu dengan menggunakan arduino pro mini. Mikrokontroler ini nantinya yang membantu perhitungan atau pemrosesan data dari hardware DS18B20 hingga didapatkan nilai suhu dalam satuan Celsius dapat dilihat pada Gambar 3. 
Table 5.

Nilai membership function setiap variabel

\begin{tabular}{ccccc}
\hline \hline Level & Rendah & Sedang & Cukup & Tinggi \\
\hline ECG & 60.00 & $72.94 \pm 9.64$ & $81.38 \pm 9.98$ & $90.55 \pm 10.6$ \\
& BPM & BPM & BPM & 9 BPM \\
GSR & $<2$ & $3-4$ & $5-6$ & $7-10$ \\
ST & $34^{\circ}-38^{\circ} \mathrm{C}$ & $30^{\circ}-34^{\circ} \mathrm{C}$ & $26^{\circ}-30^{\circ} \mathrm{C}$ & $<26^{\circ} \mathrm{C}$ \\
\hline \hline
\end{tabular}

Tabel 6.

Perbandingan HB

\begin{tabular}{cccc}
\hline \hline Percobaan & Finger Pulse Oximeter & ECG & Error \\
\hline Subjek 1 & 87 & 86.7 & 0.3 \\
Subjek 2 & 78 & 79.3 & 1.3 \\
Subjek 3 & 72 & 72.34 & 0.34 \\
Subjek 4 & 82 & 81.16 & 0.84 \\
Subjek 5 & 92 & 93.98 & 1.98 \\
& Error Total & & 0.952 \\
\hline \hline
\end{tabular}

Tabel 7.

Hasil pengujian ST

\begin{tabular}{ccccc}
\hline \hline \multicolumn{2}{c}{ Percobaan } & Termometer & DS18B20 & Error \\
\hline \multirow{2}{*}{ Subyek 1 } & Ketiak 1 & $35.8^{\circ} \mathrm{C}$ & $35.4^{\circ} \mathrm{C}$ & 0.4 \\
& Genggam 1 & $34.7^{\circ} \mathrm{C}$ & $34^{\circ} \mathrm{C}$ & 0.7 \\
Subyek 2 & Ketiak 2 & $36.1^{\circ} \mathrm{C}$ & $35.7^{\circ} \mathrm{C}$ & 0.4 \\
& Genggam 2 & $35.4^{\circ} \mathrm{C}$ & $34.7^{\circ} \mathrm{C}$ & 0.7 \\
Subyek 3 & Ketiak 3 & $36^{\circ} \mathrm{C}$ & $35.5^{\circ} \mathrm{C}$ & 0.5 \\
& Genggam 3 & $35.9^{\circ} \mathrm{C}$ & $35.5^{\circ} \mathrm{C}$ & 0.4 \\
\multirow{2}{*}{ Error Total } & & Ketiak & & 0.43 \\
& & Genggam & & 0.6 \\
\hline \hline
\end{tabular}

Tabel 8.

Perbandingan konduktansi

\begin{tabular}{ccc} 
Resistor Ohm & Tegangan V & Konduktansi uSiemens \\
\hline $100 \mathrm{~K}$ & 0.802 & 10 \\
$220 \mathrm{~K}$ & 0.132 & 4.54 \\
$330 \mathrm{~K}$ & 0.62 & 3.03 \\
$470 \mathrm{~K}$ & 1 & 2.12 \\
$560 \mathrm{~K}$ & 1.18 & 1.78 \\
$680 \mathrm{~K}$ & 1.36 & 1.47 \\
$820 \mathrm{~K}$ & 1.51 & 1.21 \\
$1 \mathrm{M}$ & 1.66 & 1 \\
$2 \mathrm{M}$ & 2.03 & 0.5 \\
$3 \mathrm{M}$ & 2.18 & 0.33 \\
\hline \hline
\end{tabular}

\section{Galvanic Skin Response (GSR)}

Galvanic Skin Response (GSR) adalah salah satu dari beberapa tanggapan elektrodermal (EDRs). EDRs adalah perubahan sifat listrik dari kulit seseorang yang disebabkan oleh interaksi antara lingkungan dan keadaan psikologis individu. Kulit manusia adalah konduktor listrik yang baik dan ketika arus listrik lemah dikirimkan ke kulit, perubahan konduksi kulit sinyal yang dapat diukur. Variabel yang diukur adalah resistensi atau timbal balik dan konduktansinya. Output dari GSR amplifier adalah konduktansi kulit dinyatakan dalam satuan yang disebut microSiemens.

Rangkaian ini terdiri dari rangkaian pembagi tegangan, rangkaian voltage follower dan rangkaian differential amplifier atau op-amp subtractor. Untuk memudahkan pengambilan data dan mencegah hal-hal yang tidak diinginkan maka dapat menggukan modul GSR. Skematik pada Gambar 4 juga sudah

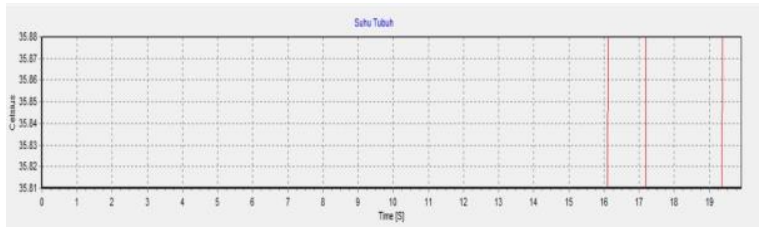

(a)

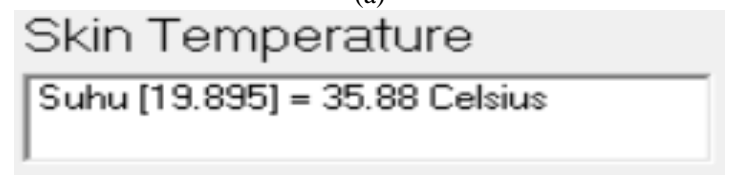

(b)

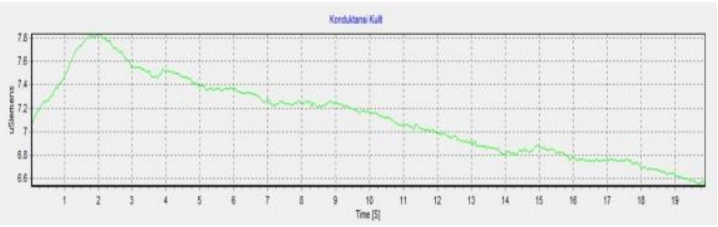

(c)

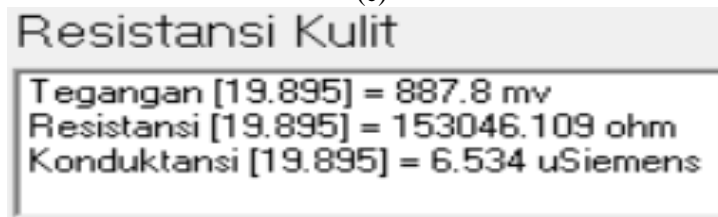

(d)

Gambar 7. (a). Grafik input ST, (b). Nilai Celsius, (c). Grafik sinyal GSR, (d). Nilai Konduktansi

sesuai dengan modul GSR sehingga baik output rangkaian dari skematik GSR ataupun modul akan memiliki nilai yang sama.

\section{E. Galvanic Skin Response (GSR)}

Software dirancang sesuai diagram blok pada Gambar 1 dengan menggunakan 3 input yang didapat dari ECG, GSR dan ST. Dari setiap inputan akan diproses menggunakan microcontroller STM32 yang berfungsi sebagai analog to digital converter (ADC).

\section{F. Pan-Tomkins}

Feature extraction secara eksplisit memberikan indeks stres dari sinyal fisiologis. Sinyal ECG langsung dinilai dengan menggunakan algoritma pencari puncak yang umum digunakan untuk mendapatkan interval R-R [4]. Proses feature extraction dilakukan untuk mengekstraksi setiap parameter yang dapat dihasilkan oleh 2 input dengan menggunakan metode PanTomkins yang memiliki beberapa tahap dalam pemrosesansnya seperti: filtering, derivative, squaring function, moving window integration, thresholding, $R$-R interval [4].

Filter merupakan metode yang bertujuan untuk mengatasi noise sehingga perlu dilakukan untuk memperbaiki kualitas sinyal gelombang QRS. Salah satunya adalah dengan filtering gelombang baik secara linear maupun secara non - linear. Bandpass filter merupakan salah satu filtering linear yang berfungsi untuk memperhalus dan menghilangkan noise pada suatu sinyal yang bekerja dengan menggantikan intensitas nilai pixel dengan rata-rata dari nilai pixel tersebut terhadap nilai pixel tetangganya. Bandpass filter telah digunakan secara luas untuk memperhalus dan mengembalikan bagian dari citra yang mengandung noise yang berbentuk bintik putih dan noise-noise 


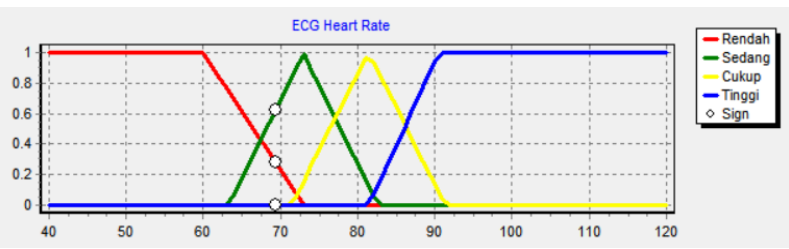

(a)

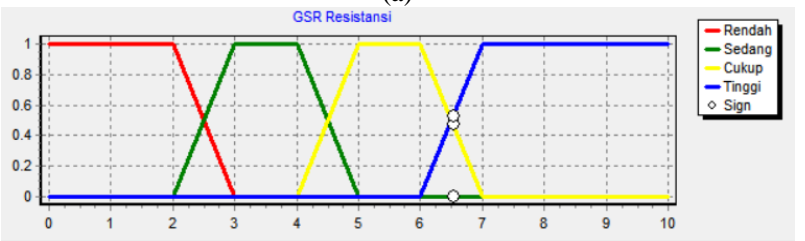

(b)

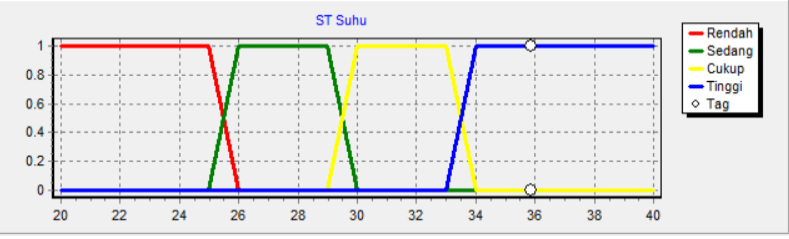

(c)

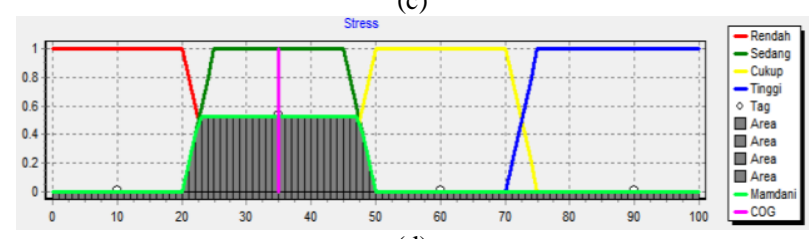

(d)

Gambar 8. Hasil fuzzifikasi (a). Miu ECG, (b) Miu resistansi, (c) Miu suhu, (d) Hasil fuzzy

yang lainnya. Bandpass filter teridiri dari 2 filter yang beriringan yaitu Highpass Filter dan Lowpass Filter yang dapat dihitung menggunakan persamaan (3.6) dan (3.7).

$$
\begin{aligned}
& y(n T)=32 x(n T-16 T-[y(n T-T)+x(n T)- \\
& x(n T)-x(n T-32 T] \\
& y(n T)=2 y(n T-T)-y(n T-2 T)+x(n T)- \\
& 2 x(n T-6 T)+x(n T-12 T)
\end{aligned}
$$

Derivative adalah tahap dimana sinyal yang telah difilter akan diproses sehingga lebih terlihat slope-nya untuk mempermudah dalam menganalisis QRS kompleks dalam pembagian P, QRS dan T. Derivative dapat dihitung menggunakan persamaan (3.8).

$$
\begin{aligned}
& y(n T)=(1 / 8 T)[-x(n T-2 T)-2 x(n T-T)+ \\
& 2 x(n T+T)+x(n T+2 T)]
\end{aligned}
$$

Squaring function adalah metode yang membuat seluruh sinyal outputan dari tahap derivative bernilai positif dengan memangkatkan sinyal inputan tersebut. Squaring function dapat dihitung menggunakan persamaan (3.9).

$$
Y(n T)=[x(n T)]^{2}
$$

Moving window integration adalah metode yang bertujuan untuk mendapatkan bentuk yang memiliki informasi dan
Table 9.

Hasil pengambilan data sebelum stroop test

\begin{tabular}{ccccccccc}
\hline \hline \multirow{2}{*}{ Nama } & ECG & GSR & ST & \multicolumn{5}{c}{ Stres } \\
\cline { 5 - 6 } & BPM & uSiemens & Celsius & R & S & C & T & \\
\hline $\begin{array}{c}\text { Subjek } \\
1\end{array}$ & 106.4 & 1.61 & 36.19 & 0 & 0.3 & 0.6 & 0 & 50.3 \\
$\begin{array}{c}\text { Subjek } \\
2\end{array}$ & 82.23 & 4.84 & 36.69 & 0 & 0.8 & 0.1 & 0 & 37.6 \\
$\begin{array}{c}\text { Subjek } \\
3\end{array}$ & 69.03 & 6.53 & 35.88 & 0 & 0.5 & 0 & 0 & 35 \\
$\begin{array}{c}\text { Subjek } \\
4\end{array}$ & 77.92 & 0.67 & 34.81 & 0.4 & 0.6 & 0 & 0 & 25.7 \\
$\begin{array}{c}\text { Subjek } \\
5\end{array}$ & 67.95 & 3.7 & 34.63 & 0.3 & 0.4 & 0 & 0 & 25.4 \\
$\begin{array}{c}\text { Subjek } \\
6\end{array}$ & 83.56 & 3.92 & 31.94 & 0 & 0.7 & 0.1 & 0 & 36.8 \\
$\begin{array}{c}\text { Subjek } \\
7\end{array}$ & 69.6 & 7.99 & 35.19 & 0 & 0.6 & 0 & 0 & 35 \\
$\begin{array}{c}\text { Subjek } \\
8\end{array}$ & 79.95 & 1.06 & 32.5 & 0.2 & 0.8 & 0 & 0 & 29.8 \\
$\begin{array}{c}\text { Subjek } \\
9\end{array}$ & 86.63 & 0.93 & 34.13 & 0 & 0.5 & 0 & 0 & 35 \\
$\begin{array}{c}\text { Subjek } \\
10\end{array}$ & 73.58 & 1.22 & 34.69 & 0.9 & 0.2 & 0 & 0 & 16.3 \\
\hline \hline
\end{tabular}

Table 10.

Hasil pengambilan data sesudah stroop test

\begin{tabular}{ccccccccc}
\hline \hline \multirow{2}{*}{ Nama } & ECG & GSR & ST & \multicolumn{6}{c}{ Stres } & \\
\cline { 5 - 6 } & BPM & uSiemens & Celsius & R & S & C & T & \\
\hline $\begin{array}{c}\text { Subjek } \\
1\end{array}$ & 100.8 & 5.39 & 34.38 & 0 & 0 & 1 & 0 & 60 \\
$\begin{array}{c}\text { Subjek } \\
2\end{array}$ & 87.02 & 4.44 & 36.44 & 0 & 0.5 & 0.4 & 0 & 46.2 \\
$\begin{array}{c}\text { Subjek } \\
3\end{array}$ & 73.35 & 9.81 & 32.88 & 0 & 0.9 & 0.2 & 0 & 39.5 \\
$\begin{array}{c}\text { Subjek } \\
4\end{array}$ & 81.54 & 7 & 35.31 & 0 & 0.1 & 0.9 & 0 & 57.3 \\
$\begin{array}{c}\text { Subjek } \\
5\end{array}$ & 77.06 & 5.83 & 33.13 & 0 & 0.5 & 0 & 0 & 35 \\
$\begin{array}{c}\text { Subjek } \\
6\end{array}$ & 88.29 & 4.36 & 34.31 & 0 & 0.6 & 0.3 & 0 & 44.3 \\
$\begin{array}{c}\text { Subjek } \\
7\end{array}$ & 72.7 & 12.32 & 35.88 & 0 & 0.9 & 0.1 & 0 & 38.1 \\
$\begin{array}{c}\text { Subjek } \\
8\end{array}$ & 90.24 & 3.56 & 36.25 & 0 & 0.9 & 0 & 0 & 35 \\
$\begin{array}{c}\text { Subjek } \\
9\end{array}$ & 84.67 & 3.17 & 36.13 & 0 & 0.6 & 0 & 0 & 35 \\
$\begin{array}{c}\text { Subjek } \\
10\end{array}$ & 79.98 & 2.68 & 36.06 & 0.2 & 0.6 & 0 & 0 & 29.0 \\
\hline \hline
\end{tabular}

membatu dalam menganalisis slope pada R. Moving window integration dapat dihitung menggunakan persamaan (3.10).

$$
\begin{aligned}
& y(n T)=(1 / N)[x(n T-(N-1) T+x(n T-N-2) T+ \\
& \cdots+x(n T)]
\end{aligned}
$$

Thresholding adalah metode yang digunakan untuk melakukan seleksi terhadap $\mathrm{R}$ wave yang akan diambil untuk melakukan perhitungan heart beat. Selain itu thresholding bertujuan menghitung interval setiap grafik yang melewati batas yang telah ditentukan dan mengambil rata-ratanya sehingga mendapatkan heart beat yang diinginkan. Heart beat dapat dihitung menggunakan persamaan (3.11).

$$
\text { TotalQRSx } \frac{60 \text { detik }}{\frac{\text { jumlah data }}{\text { frekuensisampling }}(\text { detik })} \mathrm{bpm}
$$


Table 11.

Hasil pengambilan data menggunakan survey

\begin{tabular}{cccccc}
\hline \hline \multirow{2}{*}{ Nama } & \multicolumn{4}{c}{ Stres } & \multirow{2}{*}{ Stres } \\
\cline { 2 - 5 } Subjek 1 & $\mathrm{R}$ & $\mathrm{S}$ & $\mathrm{C}$ & $\mathrm{T}$ & \\
Subjek 2 & 0 & 25 & 75 & 0 & $\mathrm{C}$ \\
Subjek 3 & 15 & 70 & 10 & 0 & $\mathrm{~S}$ \\
Subjek 4 & 5 & 50 & 35 & 0 & $\mathrm{~S}$ \\
Subjek 5 & 15 & 50 & 35 & 10 & $\mathrm{~S}$ \\
Subjek 6 & 10 & 85 & 20 & 0 & $\mathrm{~S}$ \\
Subjek 7 & 5 & 75 & 10 & 0 & $\mathrm{~S}$ \\
Subjek 8 & 0 & 80 & 10 & 10 & $\mathrm{~S}$ \\
Subjek 9 & 10 & 60 & 20 & 0 & $\mathrm{~S}$ \\
Subjek 10 & 35 & 50 & 10 & 5 & $\mathrm{~S}$ \\
\hline \hline
\end{tabular}

Table 12.

Hasil pengambilan data menggunakan sistem

\begin{tabular}{|c|c|c|c|c|c|c|}
\hline \multirow{2}{*}{ Nama } & \multicolumn{4}{|c|}{ Stres } & \multirow[b]{2}{*}{ COG } & \multirow[b]{2}{*}{ Stres } \\
\hline & $\mathrm{R}$ & $\mathrm{S}$ & $\mathrm{C}$ & $\mathrm{T}$ & & \\
\hline Subjek 1 & 0 & 0.38 & 0.61 & 0 & 50.35 & $\mathrm{C}$ \\
\hline Subjek 2 & 0 & 0.84 & 0.09 & 0 & 37.6 & $\mathrm{~S}$ \\
\hline Subjek 3 & 0 & 0.53 & 0 & 0 & 35 & $\mathrm{~S}$ \\
\hline Subjek 4 & 0.48 & 0.65 & 0 & 0 & 25.73 & $\mathrm{~S}$ \\
\hline Subjek 5 & 0.38 & 0.48 & 0 & 0 & 25.49 & $\mathrm{~S}$ \\
\hline Subjek 6 & 0 & 0.78 & 0.06 & 0 & 36.85 & $\mathrm{~S}$ \\
\hline Subjek 7 & 0 & 0.65 & 0 & 0 & 35 & $\mathrm{~S}$ \\
\hline Subjek 8 & 0.27 & 0.85 & 0 & 0 & 29.82 & $\mathrm{~S}$ \\
\hline Subjek 9 & 0 & 0.57 & 0 & 0 & 35 & $\mathrm{~S}$ \\
\hline Subjek 10 & 0.93 & 0.21 & 0 & 0 & 16.32 & $\mathrm{R}$ \\
\hline
\end{tabular}

Keterangan:

$\mathrm{R}$ : Rendah, S : Sedang, C : Cukup, T : Tinggi

\section{G. Fuzzy Logic Controller (FLC)}

Pada penelitian kali ini, digunakan Fuzzy Logic Controller (FLC) sebagai metode decision making untuk menentukan seseorang mengalami tingkatan stres tertentu. Variabel yang mempengaruhi pengambilan keputusan tersebut antara lain: Beat Per Minute (BPM) jantung (ECG), resistansi atau konduktivitas kulit (GSR) dan suhu tubuh manusia dalam celsius (ST). Membership function dari 3 variabel tersebut dapat dilihat pada Tabel 5 dan dalam bentuk tampilan program. Selain itu, salah satu komponen penting dalam penggunaan metode fuzzy adalah rules. Rules dari ketiga variabel tersebut yang tiap variabelnya memiliki 4 klasifikasi menghasilkan rules yang banyak pula. Didapatkan total 64 rules dari variasi kemungkinan pengambilan keputusan unutk metode fuzzy seperti pada Tabel 1 - Tabel 4. Sebelum itu dalam penetuan membership function dibutuhkan acuan sehingga dapat membantu dalam permbuatannya. Nilai tersebut dapat dilihat pada Tabel 5.

\section{H. Metode Validasi}

Metode pengujian untuk memvalidasi hasil tingkatan stres pada subjek dan pengaruh variabel yang digunakan terhadap stres pada manusia menggunakan metode Stroop Test. Metode stroop test adalah metode yang ditemukan oleh ahli psikologi yaitu John Ridley Stroop pada tahun 1935. Tes ini berisi tulisan yang setiap katanya memiliki warna yang berbeda.

Tujuan dari tes ini untuk mengukur pengaruh dari subjek yang diberikan uji stroop test sebelum dan sesudahnya. Karena stroop test merupakan metode yang telah banyak diketahui untuk menginduksi tekanan mental. Dalam praktiknya subjek terlebih dahulu menggunakan alat untuk mendeteksi tingkatan stresnya. Lalu setelah penggunaan alat pertama selesai subjek akan diberikan stroop test beberapa menit dan kemudian diambil lagi data tingkatan stresnya untuk dilihat apakah ada perubahan sebelum dan sesudah diberikan stroop test. Setelah data terkumpul akan dilakukan analisis terkait validasi data yang didapatkan dengan pengujian stroop test ini.

Metode stroop sest juga dirancang sedemikian rupa dengan memberikan tingkatan dalam pengujiannya yaitu mudah sedang susah. Mudah adalah soal dengan jeda 5 detik, sedang dengan jeda 3 detik dan susah dengan jeda 1 detik untuk setiap soalnya. Lama pengujiannya kurang lebih 5 menit. Subjek dituntut untuk menjawab soal dengan tepat, cepat dan melafalkannya dengan suara yang jelas. Selain metode stroop sest dilakukan juga survey dengan memberikan pertanyaan kepada calon subjek yang bertujuan untuk mengetahui kondisi psikologisnya saat itu. Dan didapatkan indikasi stres berdasarkan jawaban dari 20 soal yang diberikan. Metode survey ini dilakukan agar menjadi pembanding hasil yang didapatkan oleh alat pada tugas akhir kali ini.

\section{HASIL DAN PEMBAHASAN}

\section{A. Pengujian ECG}

Pengujian output ini bertujuan untuk melihat hasil dari rangkaian ECG secara keseluruhan sudah bekerja dengan baik atau belum. Output yang diharapkan adalah sinyal jantung yang memiliki karakteristik gelombang PQRST secara lengkap. Output rangkaian ECG dapat dilihat pada Gambar 5 dan Tabel 6 adalah hasil perbandingan nilai HB yang didapat dari finger pulse oximeter dan instrumentasi ECG.

\section{B. Pengujian ST}

Pengujian rangkaian Skin Temperature dilakukan dengan membandingkan secara langsung hasil dari rangkaian ST dengan termometer suhu badan. Pengambilan data didapat dari beberapa subjek yang diukur dari dua tempat pengukuran yaitu di ketiak dan di genggaman tangan. Hasil data pengujian dapat dilihat pada Tabel 7.

\section{Pengujian GSR}

Pengujian GSR dilakukan dengan cara memberikan input berupa resistor yang bervariasi lalu dillakukan pengukuran terhadap output sehingga didapatkan nilai tegangannya. Hasil pengujian dapat dilihat pada Tabel 8.

\section{Pengujian Integrasi Seluruh Sistem}

Setelah semua nilai didapatkan maka akan dilakukan proses integrasi seluruh sistem. Namun untuk nilai HB terlebih dahulu sinyal ECG yang harus diproses untuk mendapatkan nilai HBnya. Proses tersebut menggunakan metode Pan-Tomkins yang setiap tahapan prosesnya dapat dilahat pada Gambar 6. Setelah didapatkan seluruh nilai variabel seperti pada Gambar 7 maka akan dilanjutkan ke tahap integrasi dengan menggunakan metode fuzzy. Semua nilai variabel nantinya akan menjadi input untuk menentukan bahwa subjek berada pada tingkatan stres tertentu. Lalu didapatkan hasil dari fuzzifikasi, miu dari tiap 
variabel hingga output fuzzy keseluruhan yang berupa diagnosis tingkatan stres pada manusia seperti pada Gambar 8.

Dari program yang telah diujicobakan dapat dilakukan beberapa analisis. Untuk membership function ECG didapatkan nilai masukan sebesar 69.32 BPM yang didapatkan dari perhitungan instrumentasi yang telah dibuat. Jika digolongkan dalam membership function dari ECG heart beat didapatkan spesifikasi posisi berupa: 0.27 rendah, 0.62 sedang, 0 cukup dan 0 tinggi. Spesifikasi tersebut menunjukan bahwa dengan nilai heart beat subjek memiliki tingkat 0.62 dominan sedang, 0.27 rendah, 0 untuk tingkat stres cukup dan tinggi. 2 nilai tingkatan stres terisi disebabkan irisan pada membership function namun bisa dihipotesiskan bahwa dengan variabel heart beat ECG ini subjek diidentifikasi memiliki kecendrungan stres sedang. Untuk membership function ST didapatkan nilai masukan sebesar $35.88^{\circ} \mathrm{C}$ yang didapatkan dari perhitungan instrumentasi yang telah dibuat. Jika digolongkan dalam membership function dari ST temperatur didapatkan pesifikasi posisi berupa: 0 rendah, 0 sedang, 0 cukup dan 1 tinggi. Spesifikasi tersebut menunjukan bahwa dengan nilai temperatur subjek memiliki tingkat kestresan 1 dominan rendah, 0 sedang, 0 cukup dan 0 untuk tingkat stres tinggi. Nilai 1 suhu tinggi didapatkan karena membership function yang bersangkutan tidak terjadi irisan dengan membership fuction lainnya sehingga nilainya mutlak 1 yang berarti subjek memiliki tingkat stres rendah. Untuk membership function GSR didapatkan nilai masukan sebesar 6.53 yang didapatkan dari perhitungan instrumentasi yang telah dibuat. Jika digolongkan dalam membership function dari GSR resistansi didapatkan spesifikasi posisi berupa: 0 rendah, 0 sedang, 0.47 cukup dan 0.53 tinggi. Spesifikasi tersebut menunjukan bahwa dengan nilai resistansi subjek memiliki tingkat kestresan 0 rendah, 0 sedang, 0.47 cukup dan 0.53 untuk dominan tingkat stres tinggi. 2 nilai tingkatan stres terisi disebabkan irisan pada membership function rendah dan sedang beririsan di nilai 6.53 sehingga dapat dihipotesiskan bahwa dengan variabel resistansi GSR diidentifikasi memiliki kecendrungan stres tinggi 0.53 lebih besar dari 0.47 .

Setelah semua nilai dimiliki (nilai miu rendah, miu sedang, miu cukup, miu tinggi) maka akan lanjut ke tahap selanjutnya yaitu implikasi dan agregasi. Tahap implikasi adalah membuat rules yang pada metode ini menggunakan metode Mamdani. Rules telah dibuat dan dapat dilihat pada Tabel 1 - Tabel 4 yang dapat dibandingkan dengan hasil akhir tingkatan stres untuk mengetahui kebenarannya. Agregasi adalah tahap untuk memproses rules, hasil agregasi dan mamdani dapat dilihat pada Gambar 8 (d). Grafik arsir adalah hasil agregasi yang sesuai dengan if-then rules yang didapat dari nilai miu setiap variabel. Bila dicocokan dari membership dan nilai miu dengan rules yang telah dibuat, jika ECG adalah sedang dan GSR adalah tinggi dan ST adalah tinggi maka OUTPUT adalah sedang (0.53). Maka hasil yang ditampilkan pada Gambar 8 sesuai dengan rules pada Tabel 2. selain itu jika disesuaikan dengan COG yang dihasilkan hasilnya tepat yaitu 35 pada sumbu $\mathrm{x}$.

\section{E. Pengujian Integrasi Seluruh Sistem}

Untuk hasil pengujian menggunakan metode stroop test dengan banyak subjek 10 orang didapatkan hasil yang cukup memuaskan. Jika dilihat pada Tabel 9 dan Tabel 10 dapat kita amati beberapa variabel, salah satunya adalah variabel hasil atau COG. Nilai COG adalah nilai tingkatan stres yang menunjukan indikasi stres dari subjek. Terdapat perbedaan dari hasil sebelum dan sesudah diuji coba. Sebagai contoh subjek 2 pada saat sebelum diberikan stroop test didapatkan hasil 37.6 dan 46.24 COG setelah dilakukan stroop test. Untuk subjek 5 sebelum diberikan stroop test didapatkan hasil 25.49 dan 60 COG setelah dilakukan stroop test. Begitu juga dengan subjek lainnya, hasil yang didapatkan setelah melakukan stroop test cenderung memiliki kenaikan pada saat stres.

Untuk variabel ECG pada subjek 2 memiliki nilai 82.23 BPM sebelum dan 87.02 BPM sesudah stroop test. Untuk subjek 5 didapatkan nilai 50.35 BPM sebelum dan 35 BPM setelah stroop test. Begitu juga dengan subjek lainnya hasil yang didapatkan setelah melakukan stroop test cenderung memiliki kenaikan pada saat stres. Untuk variabel GSR pada subjek 2 didapatkan nilai 4.84 uSiemens sebelum dan 4.44 uSiemens sesudah stroop test. Sedangkan untuk subjek 5 didapatkan 3.57 uSiemens sebelum dan 5.83 sesudah stroop test. Pada subjek 2 untuk sebelum dan sesudah tes nilai yang didapatkan mengalami penurunan namun jika disesuikan kembali pada membership function nilai tersebut masih berada pada klasifikasi yang sama yaitu stres "sedang" sehingga walaupun mengalami penurunan namun masih di dalam klasifikasi yang sama. Sedangkan untuk subjek 5 hasil yang didapatkan masih sesuai teori mengalami kenaikan setelah pengujian stroop test.

Variabel ST untuk subjek 2 memiliki nilai 36.69 celsius sebelum dan 36.44 sesudah stroop test. Sedangkan subjek 5 memiliki nilai 34.63 celsius sebelum dan 33.13 celsius sesudah stroop test. Untuk 2 varibel ini memiliki kesesuaian dengan teori karena untuk variabel ST memiliki kecendrungan nilai turun jika subjek mengalami kenaikan tingkatan stres. Secara keseluruhan dapat kita lihat pada Tabel 9 dan Tabel 10 nilai sebelum dan sesudah stroop test untuk variabel ECG secara keseluruhan sesuai dengan teori yang berarti mengalami kenaikan BPM dengan tingkat korelasi $80 \%$ setelah diberikan uji coba stroop test begitu juga variabel GSR yang hampir keseluruhan nilai sesuai dengan teori dengan tingkat korelasi $90 \%$. Berbeda dengan variabel ST, hasil yang didapatkan memiliki korelasi yang rendah yaitu $40 \%$, cenderung tidak sesuai karena suhu mengalami kenaikan. Kemungkinan disebabkan kesalahan pengambilan data ketika jeda uji stroop test. Kebanyakan dari subjek tidak melepas sensor suhu dari ketiak sedangkan sensor-sensor yang lain dilepaskan. Namun secara umum hasil akhir COG memiliki kesesuai 100\% dengan teori yang mengalami kenaikan setelah dilakukan uji coba stroop test. Selain itu metode validasi menggunakan survey yang dibandingkan dengan hasil deteksi stres sistem pada Tabel 11 dan Tabel 12 juga memiliki kesusuaian yang tinggi. Dari Tabel 10 subjeknya subjek ke-10 yang tidak sesui dengan hasil survey. Hasil survey menunjukan deteksi sedang sedangkan 
pada sistem mendeteksi rendah. Ketidak sesuaian ini bisa saja terjadi dikarenakan ketidakmaksimalan dalam pengambilan data, psikologi subjek yang terlalu cepat berubah dan lain sebagainya. Namun, jika dipresentasikan kesesuaian hasil validasi antara metode survey dan sistem memiliki nilai $90 \%$. Nilai ini sudah cukup tinggi untuk menunjukan bahwa sistem yang diciptakan sudah berjalan dengan sangat baik.

\section{KESIMPULAN}

Pada tugas akhir ini diajukan sebuah instrumentasi alat yang dapat mengidentifikasi tingkatan stres menjadi 4 level dengan menggunakan 3 variabel. Instrumentasi alat ECG dan ST memiliki nilai error $0.9 \mathrm{BPM}$ dan $0.4^{\circ} \mathrm{C}$ sehingga data yang didapatkan bisa dipertanggung jawabkan. Terlebih untuk instrumentasi ECG berhasil memunculkan sinyal jantung dengan tingkat kejernihan sinyal yang tinggi terbukti dengan morfologi sinyal ECG yang sangat jelas.

Penggunaan metode Fuzzy sangat berguna untuk menentukan pengambilan keputusan dengan data-data crisp. Dari pengambilan data 10 subjek dilakukan pengujian menggunakan metode Stroop Test, hasilnya variabel ECG dan GSR memiliki korelasi yang tinggi sekitar $80 \%$ dan $90 \%$ yang berarti nilai ECG dan GSR mengalami kenaikan sesuai dengan kenaikan stres. Sedangkan untuk ST korelasinya hanya $40 \%$.
Namun secara keseluruhan berdasarkan hasil fuzzy didapati bahwa $100 \%$ subjek mengalami peningkatan stres pada saat pengujian metode Stroop Test. Hasil deteksi stres dari alat yang telah dibuat dibandingkan dengan hasil survey psikologis untuk memvalidasi hasil akhir memiliki akurasi $90 \%$ dengan satu hasil salah dan sembilan hasil deteksi benar. Ini menunjukan bahwa sistem yang diciptakan sudah berjalan dengan baik.

\section{DAFTAR PUSTAKA}

[1] N. T. Lumban Gaol, "Teori Stres: Stimulus, Respons, dan Transaksional," Bul. Psikol., vol. 24, no. 1, p. 1, 2016, doi: 10.22146/bpsi.11224.

[2] L. Vanitha and G. R. Suresh, "Hierarchical SVM to Detect Mental Stress in Human Beings Using Heart Rate Variability," Proc. IEEE Int. Caracas Conf. Devices, Circuits Syst. ICCDCS, no. October, 2014, doi: 10.1109/ICDCSyst.2014.6926145.

[3] L. Vanitha and G. R. Suresh, "Hybrid SVM Classification Technique to Detect Mental Stress in Human Beings Using ECG signals," in ICACCS 2013 - Proceedings of the 2013 International Conference on Advanced Computing and Communication Systems: Bringing to the Table, Futuristic Technologies from Around the Globe, Oct. 2014, doi: 10.1109/ICACCS.2013.6938735.

[4] K. Soman, A. Sathiya, and N. Suganthi, "“"Classification of Stress of Automobile Drivers using Radial Basis Function Kernel Support Vector Machine," in 2014 International Conference on Information Communication and Embedded Systems, ICICES 2014, Feb. 2014, pp. 15, doi: 10.1109/ICICES.2014.7034000.

[5] Maxim, "Maxim DS18B20 thermometer," vol. 92, pp. 1-22, 2008, [Online]. http://datasheets.maximintegrated.com/en/ds/DS18B20.pdf.
Available: 